\title{
Sejarah Gaya Desain Grafis Kover Album Piringan Hitam Musisi Indonesia Tahun 1961-1969 Koleksi Irama Nusantara
}

\author{
Sudjadi Tjipto R. \\ Program Studi Desain Komunikasi Visual \\ STSRD VISI Yogyakarta \\ sudjadi1980@gmail.com
}

\begin{abstract}
Documentation of musical works in Indonesia has never been noticed by stakeholders (government) from the past to the present. The absence of agencies related to documenting Indonesian music works has caused the young generation to never know good quality domestic children's music. In the past music works were first produced in the form of vinyl or in Indonesia called "Piringan Hitam / PH", then tapes, and finally on CD (Compact Disc). At the level of music lovers or collectors, Indonesian Music vinyl is the most soughtafter music artifact, of high value due to the scarcity of its production. It is "interesting to look at the beauty of the style of vinyl records in the early recording industry in Indonesia at that time.

This study would like to examine the history of the relationship between the style of design of the vinyl records in Indonesia in relation to the design style in America. Historical research methods used in the study of the style of art and design with research materials obtained from the observation of digital data (download) of the Irama Nusantara portal and literature studies from journal articles and related reference books. The results of the study showed that the relationship between vinyl design in Indonesia was influenced by the business relationship of the record label, the current design trend and the limitations of the cover designer / artist and the limitations of the printing technology at that time.
\end{abstract}

Keywords: vinyl, design graphic, record label

\section{PENGANTAR}

Sejak tahun 2013 generasi muda yang familiar dengan internet menemukan portal unik tempat mendengarkan karya musik Indonesia jadul dalam format streaming dengan sound unik yang berasal dari Piringan Hitam (PH). Adalah yayasan Irama Nusantara yang saat ini merupakan pusat database terbesar musik Indonesia dalam format digital (www.iramanusantara.org). Bermula dari sekelompok anak muda kolektor piringan hitam saat kuliah di Bandung. Dengan semangat ingin melestarikan, mendokumentasikan, dan mempopulerkan kembali segala macam genre musik Indonesia, Irama Nusantara sampai dengan bulan April
2015 telah berhasil mengunggah (upload) 940 buah album musisi Indonesia. Dalam hitungan kasar, bila dalam 1 album PH berisi 6 lagu, berarti telah tersedia 5.640 buah lagu musisi Indonesia khusus yang bersumber dari Piringan Hitam (PH). Semangat Irama Nusantara untuk mengarsipkan seluruh album rekaman musisi Indonesia tanpa mengkomersilkan dan untuk mengantisipasi pembajakan diwujudkan dalam penyediaan layanan streaming audio saja, siapapun dapat mendengarkan dengan gratis, tetapi tidak dapat mengunduh (download) file audionya.

Sejarah industri rekaman Nusantara dimulai sejak jaman penjajahan. Hasil karya lagu/rekaman musisi Indonesia saat itu dalam 
wujud Piringan Hitam (PH). Desain grafis pada kover Piringan Hitam dengan ukurannya yang besar sangat menarik untuk dikaji. Adalah Irama Nusantara sebuah yayasan nirlaba yang perduli pada pendokumentasian format digital audio (lagu) musisi Indonesia khusus dari format Piringan Hitam membuat situs secara mandiri dengan alamat www.iramanusantara.org

Menarik untuk dicermati ketika Irama Nusantara juga menampilkan 940 buah kover/sampul album PH musisi Indonesia dalam kurun waktu 1960-1980an (data tahun 2015). Dalam sejarah musik Indonesia khususnya tampilan karya desain kover Piringan Hitam (PH), baru kali ini terjadi, kita dapat melihat dengan mudah menyaksikan karya-karya desain kover PH musisi Indonesia sedemikian banyaknya. Bahkan karena kelangkaannya, banyak masyarakat yang mungkin baru pertama kali melihatnya. Dari sisi desain grafis, gaya desain kover-kover $\mathrm{PH}$ koleksi Irama Nusantara memiliki desain yang menarik. Setiap kover PH memiliki gaya desain yang berbeda-beda, mungkin disesuai dengan trend gaya desain saat itu ataupun diselaraskan dengan genre musiknya.

\section{METODOLOGI PENELITIAN KAJIAN HISTORIS DESAIN}

Penelitian ini ingin mengkaji kover Piringan Hitam musik Indonesia koleksi Irama Nusantara dengan menggunakan metode penelitian kualitatif. Metode kualitatif menuntut peneliti untuk memberikan sumbangan pada ilmu pengetahuan, tahapan penelitiannya melampaui berbagai tahapan berpikir kritis ilmiah, yang mana seorang peneliti memulai berpikir secara induktif, yaitu menangkap berbagai fakta atau fenomena- fenomena sosial, melalui pengamatan dilapangan, kemudian menganalisisnya dan kemudian berupaya melakukan teorisasi berdasarkan apa yang diamati (Bungin, 2011:6). Lebih spesifik penelitian ini menggunakan metode penelitian Historis Studi Gaya Seni Rupa dan Desain seperti yang dipaparkan oleh Sumartono (2017:113) bahwa dalam penelitian sejarah seni rupa dan sejarah desain, karya seni rupa dan penciptanya atau karya desain dan desainernya menjadi fokus utama analisis meskipun dikaitkan dengan berbagai konteks. Penelitian Model Kajian Historis Desain menurut Sachari (2005:45) didekati berdasarkan penanggalan waktu yang dinilai berdasarkan suatu momentum atau peristiwa penting yang mendasari dinamika budaya atau peradaban selanjutnya. Tidak digunakan untuk menyusun sejarah tetapi untuk mengamati sejarah satu objek secara kritis yang kemudian dapat memberi masukan, koreksi, analisis atau mendeskrepsikan pengalan-penggalan sejarah tertentu yang bermakna bagi kajian ilmu desain.

Penelitian ini meneliti gaya desain grafis cover Piringan Hitam koleksi Irama Nusantara. Perihal metode penelitian gaya desain menurut Sumartono (2017:118-119) dijelaskan bahwa pendekatan stilistik adalah pendekatan tentang 'gaya' (style). Kata style berasal dari kata bahasa latin stilus yang artinya 'alat tulis'. Dari sini munculah pandangan bahwa tulisan tangan adalah ekspresi langsung dari watak seseorang. Secara teoritis gaya bisa dianggap sebagai "sumber daya seni", sebagai sebuah faktor amat penting dalam produksi artistik dengan pengertian bahwa di dunia seni/desain terdapat banyak gaya di mana seorang seniman/desainer bisa memilih salah satu dari gaya-gaya yang digunakan atau dikembangkannya. Sumartono 
(2017:119) mengutip penjelasan Walker, (1989:155) dan Genova (1979:315-324) menyimpulkan bahwa seorang seniman/desainer juga dapat menggabungkan beberapa gaya untuk diolah menjadi sebuah gaya baru dan gaya dapat berarti juga perkawinan antara bentuk $\&$ isi.

Metode pengumpulan data yang digunakan dalam penelitian kualitatif ini adalah observasi, dan studi pustaka. Observasi secara langsung dilakukan dengan mengunduh (download) tampilan visual kover Piringan Hitam musisi Indonesia dari situs www.iramanusantara.org. Studi pustaka dilakukan dengan mengumpulan data-data tertulis dari hasil penelitian tentang musik Indonesia dan tampilan visual gaya desain grafis baik berupa Artikel jurnal, dan bukubuku yang berkaitan tema penelitian ini. Termasuk juga artikel surat kabar (cetak/online), dan majalah yang membahas tentang kover kaset, $\mathrm{CD}$, ataupun $\mathrm{PH}$ album musik Indonesia. Rumusan masalah yang diangkat dari penelitian ini adalah bagaimana sejarah gaya desain grafis pada kover Piringan Hitam musik Indonesia tahun 1960-1970 koleksi Irama Nusantara. Sedangkan tujuan penelitian untuk mengetahui sejarah ragam/bentuk gaya desain grafis pada kover Piringan Hitam musik Indonesia koleksi Irama Nusantara.

\section{PEMBAHASAN}

\section{Sejarah Awal Piringan Hitam di Indonesia}

Theodore (2013:6) memaparkan bahwa di Indonesia rekam-merekam music diyakini sudah ada di Batavia dan Surabaya pada masa pendudukan Belanda. Gramafon Columbia serta peralatan studio rekaman yang di bawa ke
Hindia Belanda awal abad ke-20 bisa dikatakan sebagai cikal bakal berdirinya industry musik Indonesia. Paling tidak catatan "Columbia Electric Recording" dari tahun 1920-an memperlihatkan sejumlah kegiatan rekaman suara; "Opname paling baroe, terbikin di tanah Jawa”. Berisi keterangan tentang lagu ataupun music yang direkam dari kelompok gamelan, orkes keroncong, wayang golek, wayang orang, dan opera.

Catatan sejarah industri Piringan Hitam di Indonesia juga dipaparkan oleh Sakrie (2015:34) bahwa pada masa Kolonial fonograf atau gramofon adalah perangkat pemutar rekaman yang mewah dan berharga mahal. Salah satu pedagang yang tersohor adalah Tio Tek Hong yang berdagang di jalan pasar baroe no.93, Batavia. Musik rekaman yang berasal dari fonograf itulah yang kemudian dimainkan oleh para pemusik Belanda, Tionghoa, Ambon, dan Manado melalui pertunjukkan panggung. Saat itu perusahaan Tio Tek Hong memulai bisnis rekamannya di tahun 1905 dengan merilis piringan hitam rekamannya keseluruh Indonesia,Tio Tek Hong bekerja sama dengan Odeon dan selanjutnya Columbia (1911-1912). Lagu-lagu yang direkam saat itu adalah jenis stambul, keroncong, gambus, kasidah, swing, musik India, hingga irama melayu. Sementara itu pada jaman Hindia Belanda awal tahun 1900-an fonograf (alat pemutar music sebelum turntable) Colombia produksi Amerika Serikat telah diimpor. Dan pada kurun waktu 19031917, berbagai label rekaman mulai masuk ke Indonesia, seperti: Gramophone Company, Odeon, Beka, Columbia, Parlophone, Anker, Lyrophon, serta bintang sapu. Sementara itu telah berdiri perusahaan rekaman lokal milik warga Tionghoa di Batavia seperti Tio Tek Hong (Pasar Baru), Lie A Kon (Pasar Senen), 
dan di kota lain; Lie Liang Swie (Surabaya), Tan Tik Hing (Semarang).

\section{Gaya Desain Grafis yang Telah Dilakukan}

Kajian desain tentang gaya desain grafis pada kaver kaset rekaman, CD (Compact Disk) musik, atau Piringan Hitam album musik Indonesia sampai saat ini belum pernah dilakukan. Penelitian gaya desain grafis sejenis yang dapat dijadikan acuan adalah penelitian tentang tata rupa sampul buku novel Indonesia. Dalam simpulan penelitiannya Wantoro (2013:87-88) menyatakan bahwa perkembangan desain sampul buku novel di Indonesia sejak masa penjajahan Belanda, kala mesin cetak pertama kali masuk ke Indonesia hingga masa kini mengalami perubahan dengan dinamika yang makin tinggi. Gaya desain grafis (tata rupa) sampul buku novel Indonesia juga semakin kaya karena dipengaruhi oleh; kemudahan referensi desain lewat media internet, gairah kebebasan berekspresi yang tinggi, menjamurnya keberadaan desainer grafis baru akibat munculannya Perguruan Tinggi jurusan Desain Grafis atau Desain Komunikasi Visual (DKV), serta kemajuan teknologi cetak yang semakin canggih, membuka peluang untuk memproduksi dengan teknik yang tak terbatas. Tetapi selain faktor diatas, iklim dan kebijakan politik yang diterapkan di Indonesia ternyata sangat menentukan tampilan sebuah desain sampul buku novel.

Sedangkan gaya desain grafis yang pertama kali muncul di jaman modern serta dianggap sangat Indonesia adalah gaya desain Indies. Dari penelitian sejarah desain grafis atas berbagai sumber (literatur, dokumen, maupun arsip-arsip visual dalam bentuk karya iklan surat kabar, majalah, dan media ruang luar)
Riyanto (2005) memaparkan bahwa gaya desain grafis Indies adalah gaya campuran antara gaya desain modern Eropa pada abad 19 s/d abad 20 (gaya Victorian, gaya Art Nouveau, gaya Plakatstil, dan gaya Art Deco) yang membaur dengan eksotisme seni rupa tradisional pribumi yang dipelopori, serta dikembangkan oleh seniman/desainer grafis Belanda. Tema ilustrasi iklan yang dirancang para seniman grafis Belanda banyak mengangkat eksotisme kehidupan masyarakat pribumi dengan segala atribut yang merupakan identitas kulturalnya melalui pandangan "kolonial sentris" (cenderung melecehkan dan menganggap kaum pribumi sebagai "the other" dengan segala perbedaan ciri-ciri genetiknya). Sebaliknya, ketika perancangan grafis iklan dilakukan oleh perancang grafis pribumi, maka obsesi genetik "menjadi Belanda" banyak mewarnai wajah visualisasi periklanan di Indonesia. Muncul bintang iklan wanita pribumi dengan anatomi dan proporsi tubuh sangat Barat (hidung mancung, kulit putih, mata cemerlang, dan bibir merekah ala bintang Holywood) meskipun tetap bersanggul menggunakan berkebaya.

Dalam pengantar tulisannya Kardinata (2015) menyatakan bahwa sejarah desain grafis juga merupakan jejak rekam perjalanan (evolusi) ide-ide dan nilai-nilai yang membawa makna....sebuah karya-bentuk, warna-tercipta bukan saya tidak lepas dari pengaruh lingkungan di sekitar desainernya: tren, gaya, aliran, tetapi juga dari perjalanan ide-ide dan nilai-nilai itu, suatu jalinan proses yang kompleks dan tak pernah berhenti. Sedangkan menurut Banindro (2007:85) Gaya (style) pada prinsipnya adalah cara menyusun atau mengkombinasikan elemen-elemen di dalam seni, sastra, disain, dan arsitektur, sehingga 
menghasilkan sebuah komposisi yang bermakna. Selanjutnya Banindro (2007:86) mengutip paparan (Arnston 1998) menyatakan bahwa gaya dalam desain grafis dapat diartikan sebagai suatu langgam yag berkembang pada jamannya yang muncul karena pengaruh perkembangan keadaan di masyarakat, baik pengaruh politik, ekonomi, maupun social yang mencul baik secara sendiri-sendiri maupun bersama-sama dalam objek desain grafis. Dalam simpulannya Banindro (2007:96) menyatakan bahwa gaya dalam desain grafis pada suatu periode cenderung muncul sebagai kontradiksi yang diakibatkan oleh kejenuhan para disainer atau disebabkan gejolak yang muncul di masyarakat, juga karena sifat dari orang-orang yang berkiprah di bidang kreatif dan artistic yang selalu mencari orisinalitas. Hal itu bagaikan siklus yang terus berputar, hilang dan suatu saat akan munncul kembali. Pada suatu masa, sebuah gaya yang dimunculkan kembali tidak serta merta sama pesis, terdapat kecenderungan yang berbeda di balik pengulangan tersebut.

Dari hasil analisis data cover piringan hitam koleksi Irama Nusantara ditemukan fakta bahwa rentang tahun produksi pembuatan $\mathrm{PH}$ tersebut antara tahun 19501970an. Dari rentang masa tersebut mengacu pada buku Graphic Style : From Victoriaan to Post-Modern (Chwast dan Heller, 1988) dan buku Tinjauan Desain Grafis, Dari Revolusi Industri hingga Indonesia Kini (Adityawan, 2010) gaya desain grafis yang muncul adalah gaya Akhir Modernisme (setelah perang dunia ke-2 selesai) kelompok gaya yang masih memiliki pengaruh dari gaya desain grafis di masa awal modern yaitu, gaya Plakat (Plakatstil) dan pengaruh dari gaya desain grafis di masa modern, yaitu Bauhaus, secara lebih terperinci gaya akhir modern tersebut meliputi gaya desain Tipografi Internasional (International Typographic Style), gaya desain Pop Art (Popular Art/Seni Populer) dan gaya desain Psycedelic. Modernisme awal adalah saat peralihan dari faham Art Noveau menuju Modernisme, kerap disebut ProtoModernisme/Early Modern. Babak ini ditandai dengan gagasan untuk meninggalkan ornamen dengan cara memadukan unsur estetika dan rekayasa. Usaha untuk mencapai penjualan tertinggi di lakukan dengan membuat iklaniklan yang tak lazim. Iklan dan kemasan produk di buat dengan skill yang tinggi oleh seniman dan desainer terkenal. Dalam kurun waktu ini kemudian muncul gaya desain yang menggunakan warna-warna plakat/flat yang disebut dengan Plakatstil.

\section{Gaya Desain Grafis American Kitsch}

Kardinata (2015:94) menjelaskan bahwa Modernisme akhir (1945-1970) didominasi oleh inovasi-inovasi yang terjadi di Amerika. Terinspirasi oleh pendekatan-pendekatan seniman garda depan (avant garde) Eropa, seniman-seniman Amerika mengembangkan gaya personal yang unik, dan bintang-bintang baru lahir. Ciri karakteriktik visual: bentukbentuk geometris yang longgar (semi geometric shapes), kasual (casual) atau tak formal, tipografi tanpa dekorasi atau ornamen, sederhana tapi fungsional (fungsi menentukan bentuknya), teks dan gambar yang terintegrasi, elemen-elemen yang saling bertumpuk (overlapping), bentuk-bentuk direduksi hingga ke dasarnya, bentuk tipografi menjadi gambar yang mengekspresikan pesan, kontras yang ekstrem pada format objek-objeknya, kolase foto atau huruf. 
Sedangkan pada tahun 1950-an Chwast \& Heller (1988:203) menjelaskan pada pertengahan tahun 1950, beberapa desainer \& Ilustrator memunculkan gaya alternatif ketika mereka melakukan pendekatan grafis bergaya lama (vintage). Gaya yang sebelumnya telah dianggap usang seperti; gaya lukisan primitif, gaya Victoria, gaya Art Nouveau dan gaya Art Deco dicomot motifnya sebagai sumber inspirasi pada gaya Pop Art. Gaya ini mendapatkan apresiasi dari para desainer, tetapi tidak sesuai jika diterapkan pada komunikasi iklan global. Gaya Revivalisme lebih pas digunakan pada sampul buku, cover PH (album rekaman), poster kegiatan budaya, serta kemasan produk. Lebih spesifik Kardinata (2015:102) menyebutnya American kitsch (Fifties Art), kata 'kitsch' berasal dari bahasa Jerman, artinya: selera buruk. Dalam dunia seni berarti vulgar, mengganggap diri penting, atau sentimen yang berlebihan. Sebagai sebuah gaya lebih populer Seni 50-an (fifties Art) dibanding 'kitsch'. Kebanyakan desain kisch memiliki nuansa aerodinamik, termasuk bentuk palet ukis yang seperti ginjal atau biji kacang merah yang menginspirasi berbagai produk seperti furniture, dan peralatan rumah tangga yang lain. Ciri karakteriktik visual: gaya huruf kasual, atau ditulis tangan (hand-written), tata letak tak-formal (informal), garis/bentuk melengkung (curvilinear), ilustrasi bergaya kartun/karikatur, ekspresi dan pose berlebihan/dramatis.

\section{Alex Steinweiss Pelopor Gaya Desain Grafis}

\section{PH Amerika 1950an}

Menurut Kohler (1999:9) bahwa pada decade 1940-an adalah pertama kalinya seni sampul album muncul dan berkembang matang pada tahun 1950-an. Kohler (1999:13) memaparkan pada tahun 1940, cara memasarkan dan mengemas $\mathrm{PH}$ berubah secara dramatis, sejak perusahaan rekaman Columbia mengeluarkan $\mathrm{PH} 78$ inc yang mempopulerkan single Rodgers dan Hart. Yang membuat album tersebut berbeda dengan $\mathrm{PH}$ lainnya adalah desain cover $\mathrm{PH}$ tersebut di desain khusus oleh seorang desainer muda bernama Alex Steinweiss. Steinweiss direkrut oleh sebuah label rekaman baru bernama Columbia pada tahun 1939, sebagai desainer pertama yang khusus menangani periklanan dan promosi (setahun setelah CBS membeli dan merestrukturisasi sebuah perusahaan rekaman lama). Steinweiss merancang poster, katalog, dan bahan promosi lainnya. Tetapi, seperti label lainnya, Columbia tidak berniat menghabiskan anggarannya hanya untuk memproduksi cover albumnya, mereka tetap mengandalkan cover $\mathrm{PH}$ generik yang bercirikan font emas dengan teknik cetak timbul (emboss) yang telah digunakan sejak 1920-1930an.

Steinweiss datang dengan banyak ide kreatif pembuatan sampul $\mathrm{PH}$ sesaat setelah ia direkrut. Meskipun pertama kali Columbia menolak, idenya akhirnya direalisasikan. Dipasaran cover album $\mathrm{PH}$ yang di desain Steinweiss ternyata disukai, dan menaikkan angka penjualan secara drastis. Akhirnya Columbia menyadari bahwa besarnya biaya produksi tambahan yang dipebutuhkan untuk memproduksi sampul $\mathrm{PH}$ Steinweiss, sebanding dengan naiknya angka penjualan $\mathrm{PH}$, dibandingkan dengan album sejenis yang dikeluarkan sebelumnya dengan cover $\mathrm{PH}$ polos (konvensional). Dengan keberhasilan itu popularitas Steinweiss kemudian meroket, departemen pemasaran Columbia kemudian 
meminta Steinweiss untuk mendesain semua cover PH rilisan berikutnya. Kemudian muncul 23 cover PH dengan gaya desain \& teknik cetak baru yang dikerjakan sendiri oleh Steinweiss. Semenjak saat itu gaya desain grafis, cara pengemasan, serta pemasaran $\mathrm{PH}$ dalam industri musik berubah. Steinweiss menangani pekerjaan tersebut sendirian, kemudian untuk membentu Steinweiss Columbia merekrut asisten desainer lepas (freelance) untuk mengatasi volume pekerjaan yang semakin tinggi. Para desainer lepas tersebut adalah Jim Flora, Robert Jones, Jim Amos, dan Sydney Butchkes. Dalam waktu satu tahun setelah Steinweiss muncul, kesuksesan desain-desain cover PH Steinweiss kemudian diikuti oleh perusahaan rekaman lain, seperti: Victor dan Decca. Tetapi nama Alex Steinweiss tetap dikenang sebagai desainer pelopor sampul $\mathrm{PH}$ yang fenomenal di tahun 40 -an.

\section{Kemunculan Industri PH di Indonesia 1950}

Tonggak sejarah monumental PH di Indonesia menurut Sakrie (2015:2-3) adalah saat berdirinya perusahaan rekaman Irama berdiri, yaitu awal era 1950-an. Lebih lanjut Theodore (2013:8) menjelasan bahwa adalah Sujono Katamso yang akrab disapa dengan mas Yos pria yang pernah berdinas menjadi penerbang Angkatan Udara Republik Indonesia hingga berpangkat komodor tahun 1952. Pada tanggal 17 Mei 1951 berdilah industri musik Indonesia "The Indonesian Music Company Limited" yang dikenal dengan label Irama.

Menurut penjelasan Sakrie (2015:4) Industri rekaman pada saat itu yang menjadi kiblat musik adalah Amerika Serikat. Bahkan di depan nama para penyanyi wanita diberi embel-embel seperti Miss Tjitjih, Miss Riboet,
Miss Roekiyah, dst. Hubungan industri musik Indonesia Amerika tersebut ternyata sudah dimulai jauh sebelum Irama berdiri. Theodore (2013:7-8) menyatakan bahwa Dalam periode ini juga terdapat sejumlah rekaman lagu Indonesia yag produksinya dilakukan di negeri lain. PH "kerontjong Aseli Muritsku sirene" yang dinyanyikan Sulami dengan iringan Canary Orkest dan diterbitkan Canary Records tahun 1926 adalah made in India. Sementara "kerontjong Boeroeng Nori" yang dinyanyikan Miss Ijem dengan iringan orkest Nirom II Bandoeng diproduksi Ultraphon, Jerman, awal decade tahun 1930-an. Kemudian beredar juga rekaman Orkes Gambus (OG) pimpinan syech Albar di atas PH Radio Corporation of America (RCA) Records.

Kejelasan hubungan Irama dengan industri musik Amerika seperti dijelaskan oleh Theodore (2013:12) bahwa untuk mengembangkan Irama mas Yos mengunjungi pabrik PH RCA Victor of Japan, RCA (Radio Corporation of America), Dot dan Finebuilt Manufacturing di Amerika Serikat, Deutsche Grammaphon Geschellshaft (Pabrik PH Polydor) di Hanover Jerman Barat dan Philips di Belanda, dalam usahanya mengembangkan perekaman lagu Indonesia. Hasilnya selain memperoleh pengetahuan lebih jauh mengenai dunia rekaman music, mas Yos juga dipercaya mencetak dan mengedarkan $\mathrm{PH}$ dari perusahaan Jepang, Amerika, dan Eropa di Indonesia. Sebagai imbalan Irama membayar royalty untuk setiap $\mathrm{PH}$ yang berhasil dijualnya.

Sementara keadaan Indonesia saat tahun 1950-an menurut Kardinata (2015:109) pada tahun-tahun pertama setelah kemerdekaan, industri percetakaan di Indonesia kurang berkembang karena sulitnya bahan baku kertas. 
Kemudian mulai tumbuh kembali di awal tahun 50-an. Pada periode itu berbagai majalah yang muncul umumnya dicetak hitam putih kecuali halaman sampul. Sejalan dengan tumbuhnya industri penerbitan, berkembang pula iklan-iklan yang disajikan pada majalah hiburan, umumnya berupa iklan dengan permainan huruf dan piktogram. Sedangkan pada tahun 1960-an sesudah PD II, teknik fotografi mulai memegang peranan penting dalam penyusunan karakter (typesetting). Pada awalnya pengoperasian Linotype dan Monotype digeser dengan mengganti sistem matriks yang digunakan saat percetakan karakter (typecasting) dengan foto matriks yang memungkinkan operator bisa memotret setiap huruf, sementara mekanisme penyeleksian dan perakitannya tetap sama.

\section{Analisis Gaya Desain Grafis}

Hasil pencarian data dari koleksi sampul PH Irama Nusantara yang memiliki tahun produksi tertera di websites nya adalah 62 buah cover PH berangka tahun 1961 s/d 1969. Data kemudian direduksi dengan cara memilih 1 cover $\mathrm{PH} /$ tahun dengan pertimbangan pemilihan gaya desain grafis yang berbeda pada tiap cover, hasilnya ditemukan 9 desain cover PH musisi Indonesia. Adapun hasil data \& analisisnya adalah sebagai berikut ini:

\section{KESIMPULAN}

Gaya desain grafis yang terdapat pada 10 desain cover $\mathrm{PH}$ koleksi Irama Nusantara adalah gaya desain Plakat, gaya desain Bauhaus, gaya desain, dan American kitsch. Dari semua gaya desain tersebut yang paling menarik adalah gaya desain American kitsch yang khusus untuk cover $\mathrm{PH}$ di pelopori oleh desainer Columbia Record Alex Steinweiss. Gaya desain grafis yang diaplikasikan di $\mathrm{PH}$ musisi Indonesia saat itu muncul karena beragam aspek yang saling berkaitan, seperti yang diungkapkan pada paparan diatas. Terdapat pengaruh desain diluar Indonesia (Amerika, Alex Steinweiss) yang didapatkan dari standar yang ditetapkan oleh perusahaan Amerika untuk distribusi PH Barat di Indonesia yang kemudian lambat laun mempengaruhi pandangan atau'taste' pemilik perusahaan rekaman Indonesia, bahwa gaya desain grafis yang bagus adalah seperti itu.

Terdapat juga tren industri rekaman yang berkiblat pada Amerika Serikat, mulai dari teknik cara mernyanyi, busana panggung, sampai dengan gaya desain cover $\mathrm{PH}$, lebih detai pada penggunaan font, warna, pose foto dan layout. Keterbatasan wawasan desain pada SDM perusahaan rekaman (desainer/seniman sampul $\mathrm{PH}$ ) termasuk keterbatasan teknologi percetakan di Indonesia pada masa-masa awal tahun 1950-1960an.

\section{DAFTAR PUSTAKA}

[1] Adityawan, Arief. 2010.Tinjauan Desain Grafis, Dari Revolusi Industri hingga Indonesia Kini. Jakarta: PT Concept Media

[2] Bungin, Burhan. 2011. Penelitian Kualitatif: Komunikasi, Ekonomi, Kebijaksanaan Publik, dan Ilmu Sosial Lainnya. Jakarta: Kencana

[3] Chwast, Seymour, dan Heller, Steven.1988.Graphic Style: From Victoriaan to Post-Modern. London : Thames \& Hudson

[4] Kardinata, Hanny.2015.Desain Grafis Indonesia dalam Pusaran Desain Grafis Dunia I. Jakarta: DGI Press 
[5] Kohler, Eric.1999.In The Groove:Vintage Record Graphics 1940-1950.San Francisco: Chronicle Books

[6] Sachari, Agus.2005.Pengantar Metode Penelitian Budaya Rupa (Desain, Arsitektur, Seni Rupa dan Kriya).Jakarta: Penerbit Erlangga

[7] Sakrie, Denny. 2015. 100 Tahun Musik Indonesia.Jakarta: Gagas Media

[8] Sumartono.2017.Metodologi Penelitian Kualitatif Seni Rupa dan Desain.Jakarta:Pusat Studi Reka Rancang Visual \& Lingkungan FSRD Universitas Trisakti

[9] Theodore, KS.2013.Rock 'n Roll Industri Musik Indonesia, Dari Analog ke Digital.Jakarta: Penerbit Buku Kompas

\section{Jurnal}

[1] Riyanto, Bedjo.2009. Gaya Desain Indies: Gaya Desain Grafis Indonesia Tempo Doeloe. Jurnal Nirmana Vol. 1. Surabaya: DKV Universitas Petra.

[2] Wantoro.2013. Napak Tilas Tata Rupa dan Cetak Sampul Novel di Indonesia. Jurnal Visualita, Vol.5 No.1.Agustus 2013.Hal. 76-88. Bandung: Program Studi DKV Universitas Komputer Indonesia

[3] Banindro, Baskoro Suryo.2007.Psychedelia dalam Rupa dan Musik dalam Widowati \& Mayasari (ed). Irama Visual, dari Toekang Reklame sampai Komunikator Visual. Yogyakarta: Jalasutra, Hal 85-98.

\section{Surat Kabar}

Media Indonesia - "Gerakan Digitalisasi Arsip" Minggu, 7 Desember 2014.

\section{Website}

http://www.Iramanusantara.org. (diakses, 1 April 2015) 